Jurnal Bisnis dan Kajian Strategi Manajemen

Volume 2 Nomor 2, 2018

ISSN : 2614-2147

http://jurnal.utu.ac.id/jbkan

\title{
MANAJEMEN PEMANFAATAN FAKTOR PRODUKSI KARET DI KECAMATAN SAMATIGA
}

\author{
Yasrizal \\ Universitas Teuku Umar \\ yasrizal@utu.ac.id
}

\begin{abstract}
Abstract: Keret plants are one of the commodities of the plantation sector and the largest contributor to PRDB in Aceh Province after oil palm. The statistics center noted that there were 144,291 tons of rubber production in Aceh Province but its productivity was only 0.61 percent. The planned productivity of rubber plant production is caused by production factors that have not been maximized. This research is a primary research, which is the population and sample in this study are all rubber farmers and entrepreneurs in Samatiga District, West Aceh. Data analysis uses a method of analyzing descriptions about the development of production and using multiple linear regression methods for influence analysis. From the results of the research, it can be concluded that the land area and capital have a positive and significant effect on rubber production in Samatiga, the variable that has the greatest influence on rubber production is the use of capital which includes the use of fertilizers and the use of superior seeds.
\end{abstract}

key words: Rubber Production, Land Area and capital

\begin{abstract}
Abstrak: Tanaman keret merupakan salah satu komoditi sektor perkebunan dan penyumbang PRDB terbesar di Provinsi Aceh setelah kelapa sawit. Badan pusat statistik mencatat bahwa ada sebesar 144.291 ton produksi karet di Provinsi Aceh namun produktivitasnya hanya 0,61 persen. Rencahnya produktivitas produksi tanaman karet disebabkan oleh faktor-faktor produksinya yang belum maksimal. Penelitian ini merupakan penelitian primer, yang menjadi populasi dan sampel dalam penelitian ini adalah seluruh petani dan pengusaha karet yang ada di Kecamatan Samatiga Aceh Barat. Analisi data menggunakan metode analisis deskripsi tentang tentang perkembangan produksi dan menggunakan metode regresi linier berganda untuk analisis pengaruh. Dari hasil penelitian yang diperoleh dapat ditarek kesimpulan bahwa luas lahan dan modal berpengaruh positif dan signifikan terhadap produksi karet di Samatiga, variabel yang paling besar pengaruhnya terhadap produksi karet adal penggunaan modal yang meliputi penggunaan pupuk dan penggunaan bibit unggul.

Kata Kunci: Produksi Karet, Luas Lahan dan modal
\end{abstract}




\section{LATAR BELAKANG MASALAH}

Terdapat 3 jenis perkebunan karet yang ada di Indonesia, yaitu Perkebunan Rakyat (PR), Perkebunan Besar Negara (PBN) dan Perkebunan Besar Swasta (PBS). Dari ketiga jenis perkebunan tersebut, PR mendominasi dari luas lahan yang mencapai 2,9 juta hektar atau sekitar 85 persen dari lahan perkebunan karet. Dengan sedemikian luasnya perkebunan karet yang dikelola rakyat, keterkaitan penyerapan tenaga kerja dan sebagai sumber pendapatan rakyat diharapkan dapat ditingkatkan dengan pengelolaan yang terpadu. Perkebunan besar diharapkan dapat menjalin program kemitraan dengan petani agar nilai tambah dari pengelolaan perkebunan rakyat dapat optimal diantaranya dengan kemitraan di bidang pemasaran, pembinaan produksi hingga pembiayaan yang berkesinambungan. Komoditi karet menjadi komoditi andalan dan memegang peranan penting dalam mendorong perekonomian masyarakat di Provinsi Aceh. Tanaman keret merupakan salah satu komoditi penyumbang PRDB terbesar di Provinsi Aceh setelah kelapa sawit. Hal ini ditunjukkan pada Tabel 1.1 berikut :

\section{Tabel 1.1}

Produksi Komoditas Andalan Provinsi Aceh

\begin{tabular}{|c|l|c|c|c|}
\hline No & \multicolumn{1}{|c|}{ Komoditas } & $\begin{array}{c}\text { Luas Areal } \\
(\mathrm{Ha})\end{array}$ & $\begin{array}{c}\text { Total Produksi } \\
\text { (Ton) }\end{array}$ & $\begin{array}{c}\text { Produktivitas } \\
\text { (Ton) }\end{array}$ \\
\hline 1 & Kelapa Sawit & 365.996 & 572.953 & 1,57 \\
\hline 2 & Karet & 144.291 & 87.407 & 0,61 \\
\hline 3 & Kakao & 89.512 & 37.594 & 0,42 \\
\hline 4 & Kopi & 24.993 & 54.580 & 2,18 \\
\hline
\end{tabular}

Sumber: BPS Provinsi Aceh (2016)

Berdasarkan Tebel 1.1 dapat dilihat bahwa terdapat empat komoditi unggulan di Provinsi Aceh yakni kelapa sawit, karet, kakao dan kopi. Dimana produksi paling tinggi yaitu tanaman kelapa sawit yakni sebesar 572.953 ton pada tahun 2015 dengan luas lahan 365.996 Ha. Sedangkan yang terendah diantara empat (4) komoditi tersebut yaitu kopi yang hanya sebesar 54.580 ton dengan luas lahan $24.993 \mathrm{Ha}$. Sedang komoditi karet menempati urutan kedua setelah kelapa sawit dengan produksi 87.407 ton pada tahun 2015. Namun jika dilihat dari tingkat produktivitas tanama kopi lebih tinggi dari pada komoditi lainya yakni mencapai 2,18 ton dan produktivitas terendah adalah tanaman kakao yaitu 0,42 ton. Sedangkan tanaman karet memiliki tingkat produkitivitas 0,61 ton pada tahun 2015 . Berdasarkan data tersebut menunjukkan bahwa tingkat produktivitas karet di Provinsi Aceh masih sangat rendah hal ini disebabkan oleh usia tanaman karet banyak sudah tua disamping itu, disamping itu berkurangnya minat tenaga kerja untuk bekerja pada lahan karet juga turut menurunkan tingkat produksi dan produktivitas.

Lebih lanjut menurut data BPS luas lahan karet terbesar di Provinsi Aceh pada tahun 2015 berada di Kabupaten Aceh Barat yakni 24.097 Ha dengan tingkat produksi sebesar 22.633,45 ton per tahun. Luas lahan karet di Kabupaten Aceh Barat berada diseluruh kecamatan yang di selanjutnya di uraikan pada Tabel berikut 
Jurnal Bisnis dan Kajian Strategi Manajemen

Volume 2 Nomor 2, 2018

ISSN : 2614-2147

http://jurnal.utu.ac.id/jbkan

Tabel 1.2

Jumlah Luas Lahan dan Produksi Karet Kabupaten Aceh Barat Tahun 2015

\begin{tabular}{|c|l|r|r|c|}
\hline No & \multicolumn{1}{|c|}{ Kecamatan } & $\begin{array}{c}\text { Luas Areal } \\
\text { (Hektar) }\end{array}$ & \multicolumn{1}{c|}{$\begin{array}{c}\text { Produksi } \\
\text { (Ton/Ha) }\end{array}$} & $\begin{array}{c}\text { Produktivitas } \\
\text { (Ton) }\end{array}$ \\
\hline 1 & Johan Pahlawan & 395 & 103,5 & 0,26 \\
\hline 2 & Samatiga & $2.268,06$ & $2.519,87$ & 1,11 \\
\hline 3 & B u b o n & $1.797,00$ & $1.615,43$ & 0,90 \\
\hline 4 & Arongan Lambalek & $2.550,66$ & $2.420,67$ & 0,95 \\
\hline 5 & Woyla & $2.070,76$ & $1.604,31$ & 0,77 \\
\hline 6 & Woyla Barat & $4.441,87$ & $5.521,86$ & 1,24 \\
\hline 7 & Woyla Timur & $1.953,91$ & $1.011,24$ & 0,52 \\
\hline 8 & Kaway XVI & $2.837,21$ & $2.520,42$ & 0,89 \\
\hline 9 & Meureubo & $2.093,69$ & $2.071,46$ & 0,99 \\
\hline 10 & Pante Ceureumen & $2.048,00$ & $1.726,97$ & 0,84 \\
\hline 11 & Panton Reu & 795,5 & 281,25 & 0,35 \\
\hline 12 & Sungai Mas & $1.351,11$ & $1.236,47$ & 0,92 \\
\hline \multicolumn{2}{|l|}{ Jumlah } & $24.602,77$ & $22.633,45$ & 0,92 \\
\hline \multicolumn{2}{|l|}{ Rata-rata } & 2050,2308 & 1886,1208 & 0,81 \\
\hline
\end{tabular}

Sumber : Badan Pusat Statistik Kabupaten Aceh Barat (2016)

Berdasarkan Tabel 1.2 tersebut dapat dilihat bahwa jumlah luas lahan karet di Kabupaten Aceh Barat sebesar 24.602,77 Ha dengan jumlah produksi 22,633,45 ton pada tahun 2015. Jika dilihat berdasarkan Kecamatan luas lahan terbesar berada pada Kecamatan Woyla Barat yaitu 4.441,87 Ha dengan jumlah produksi 5.521,86 ton. Sedangkan yang terendah berada pada Kecamatan Johan Pahlawan dengan luas lahan 395,00 Ha dan produksi 103,50 ton pada tuhun 2015

Lebih lanjut jika dilihat dari tingkat produktivitas karet maka Kecamatan Samatinga merupakan salah satu daerah yang memiliki tingkat produktivitas paling tinggi setelah Kecamatan Woyla Barat yakni 1,11 ton per tahun sedikit lebih kecil jika dibandingkan dengan Kecamatan Woyla Barat yaitu 1,24 ton per tahun.

Petani karet rakyat di Kabupaten Aceh Barat khususnya di Kecamatan Samatiga digolongkan menjadi tiga kelompok petani yaitu petani pemilik, petani penyadap dan petani pemiliki penyadap. Kelompok petani pemilik adalah petani karet yang umumnya memiliki areal perkebunan karet yang cukup luas sehingga membuat petani tersebut tidak mampu untuk memanen (menders) sendiri lahan perekebunan karet yang dimilikinya. Kelompok ini umumnya berperan dalam persiapan tanam serta melakukan perawatan seperlunya hingga tanaman karet siap untuk disadap lalu buruh potong yang menders tanaman karet tersebut.

Menurut keterangan petani sistem bagi hasil merupakan pola yang umum dilakukan dalam jalinan kemitraan antara pemilik dan penyadap biasanya dengan 
pola-pola 1:2, 1:3, 1:4 tergantung pada usia dan produktivitas tanaman karet. Pola 1:2 biasanya untuk karet unggul dengan pembagian 1 untuk penyadap dan 2 untuk pemilik. Kelompok petani karet rakyat kedua adalah petani penyadap yang umumnya adalah petani yang tidak memiliki lahan karet sendiri. Fenomena yang ditemukan dalam usaha perkebunan karet rakyat khususnya yang dikelola dengan sistem bagi hasil adalah penguasaan teknologi oleh buruh potong sebagai tenaga sadap dan pengolahan getah menjadi bokar yang siap dipasarkan.

Berdasarkan latar belakang yang telah diuraikan diatas maka penulis tertarik melakukan penelitian lebih lanjut dengan judul "Faktor-Faktor Yang Mempengaruhi Produksi Karet di Kecamatan Samatiga Kabupaten Aceh Barat”.

Berdasarkan uraian tersebut, maka permasalahan dapat dirumuskan adalah faktor-faktor apa sajakah yang mempengaruhi produksi karet di Kecamatan Samatiga Kabupaten Aceh Barat?

\section{TINJAUAN PUSTAKA}

\section{Fungsi Produksi}

Menurut Sudarman (2004, h. 108) fungsi produksi adalah suatu skedul (atau tabel atau persamaan matematis) yang menggambarkan jumlah output maksimun yang dapat dihasilkan dari satu set faktor produksi tertentu, dan pada tingkat teknologi tertentu pula. Singkatnya, fungsi produksi adalah katalog dari kemungkinan hasil produksi.

Selanjutnya menurut Sukirno (2006, h. 204) fungsi produksi dapat didefinisikan dalam dua pengertian yaitu :

1. hubungan diantara tingkat produksi yang dapat dicapai dengan faktor-faktor produksi yang digunakan untuk mewujudkan tingkat produksi tersebut.

2. Suatu kurva yang menunjukkan tingkat produksi yang dicapai dengan berbagai jumlah tenaga kerja yang digunaka

Menurut Pindyck \& Rubinfeld (2009, h. 211) Perusahaan dapat mengubah input menjadi output dengan berbagai cara, dengan menggunakan variasi tenaga kerja, bahan-bahan produksi dan modal. Proses dan produk yang dihasilkan dalam sebuah fungsi produksi. Sebuah fungsi produksi menunjukkan output tertinggi "q" yang dapat dibuat oleh perusahaan untuk sebuah kombinasi tertentu input produksi. Secara matematis fungsi produksi dapat dirumuskan :

$$
\mathrm{Q}=\mathrm{F}(\mathrm{K}, \mathrm{L})
$$

\section{Faktor Yang Mempengaruhi Produksi Karet}

Usaha tani adalah suatu tempat atau bagian permukaan bumi dimana pertanian diusahakan oleh seorang petani tertentu, apakah ia seorang petani, pemilik, penyakap, atau manajer yang digaji. Dengan kata lain usaha tani merupakan himpunan dari sumber-sumber daya alam yang ada dan digunakan untuk produksi pertanian. 
Kegiatan produksi memerlukan unsur-unsur yang dapat digunakan dalam proses produksi yang disebut faktor produksi. Faktor-faktor produksi yang bisa digunakan dalam proses produksi yang terdiri atas adalah segala sesuatu yang disediakan oleh alam yang dapat dimanfaatkan untuk memenuhi kebutuhannya.

\section{Luas Lahan}

Tanah atau lahan merupakan pabrik hasil-hasil pertanian dimana produksi berjalan dan dari mana produski keluar, akan tetapi kesuburan tanah sangat mempengaruhi produksi yang dihasilkan. Area tanah yang dimiliki suatu negara dalam kaitannya dengan keragaman, kesuburan dan topografinya sudah barang tentu akan mempengaruhi manfaat ekonomisnya ( Sugiarto (2007,h.4).

Tanah sebagai salah satu faktor produksi biasanya terdiri dari barang ekonomi atau material yang diberikan oleh alam tampa bantuan manusia. Istilah tersebut bukan hanya meliputi permukaan tanah dan air, melainkan segala sesuatu yang terkandung didalamnya. Luas lahan sangat berpengaruh terhadap produksi karet karena dengan semakin luas lahan yang dimiliki maka akan semakin banyak tanaman karet yang dapat ditanam. Luas lahan pertanian juga akan mempengaruhi skala usaha dan pada akhirnya akan mempengaruhi efisien atau tidaknya suatu usaha pertanian (Nababan 2009, h. 4).

\section{Modal}

Modal merupakan barang atau hasil produksi yang digunakan untuk menghasilkan produk lebih lanjut. Modal merupakan faktor produksi yang meliputi semua jenis barang yang dibuat untuk menunjang kegiatan produksi barang-barang lain serta jasa-jasa. Pengertian modal semacam ini sebenarnya hanyalah merupakan salah satu dari pengertian seluruhnya sebagai mana yang sering dipergunakan oleh ahli ekonomi. Sebab, modal juga mencakup uang yang tersedia didalam perusahaan untuk membeli mesin-mesin serta faktor produksi lainnya (Rosyidi 2009, h 55).

Menurut Kasmir (2009, h. 84-85) pada dasarnya kebutuhan untuk melakukan usaha terdiri dari dua jenis yaitu:

a. Modal Investasi

Modal investasi digunakan untuk jangka panjang dan dapat digunakan berulang-ulang. Biasanya umurnya lebih dari satu tahun. Pengunaan modal investasi jangka panjang adalah untuk membeli aktiva tetap seperti tanah, bangunan/gedung, mesin, peralatan, kendaraan, serta investasi lainnya. Modal investasi merupakan porsi terbesar dalam komponem dalam pembiayaan dalam suatu usaha dan biasanya dikeluarkan pada awal perusahaan didirikan atau untuk perluasan pabrik. Modal investasi biasanya diperlukan dari modal pinjaman berjangka waktu panjang (lebih dari satu tahun). Pinjaman ini biasanya diperoleh dari perbankan.

b. Modal Kerja 
Modal kerja yaitu modal yang digunakan unuk membiayai operasional perusahaan pada saat perusahaan sedang beroperasi. Jenis modal modalnya bersifat jangka pendek, biasanya hanya digunakan untuk sekali atau beberapa kali proses produksi. Modal kerja digunakan untuk keperluan untuk membeli bahan baku, membayar gaji karyawan dan biaya pemeliharaan serta biaya lainnya.

\section{Penelitian Terdahulu}

Setiadi (2012) melakukan penelitian dengan judul Faktor-Faktor Yang Mempengaruhi Produksi Karet PT. Perkebunan Nusantara IX (Persero). Hasil analisis juga menunjukan bahwa pemakaian tenaga kerja (HKO) panen, pupuk urea, pupuk TSP, pupuk KCL, luas lahan, umur tanaman dan curah hujan secara bersamasama berpengaruh nyata terhadap produksi. Trend produksi karet setiap kebun berbeda, ada yang mempunyai kecenderungan meningkat dan ada yang mempunyai kecenderungan menurun.

Selanjutnya Syabidal (2014) melakukan penelitian dengan judul FaktorFaktor Yang Mempengaruhi Produksi Karet (Heavea Brasiliensis) di Kecamatan Seunagan Timur Kabupaten Nagan Raya. Tujuan penelitiannya adalah menganalisis seberapa besar pengaruh luas lahan, harga input pupuk (urea, TSP, KCL) dan upah tenaga kerja berpengaruh terhadap produksi karet di Kecamatan Seunagan Timur Kabupaten Nagan Raya. Penelitian ini menggunakan data sekunder yaitu data time series dari tahun 2000-2012.

\section{METODE DAN MODEL ANALISIS DATA}

Penelitian ini merupakan penelitian primer, dengan mengambil data langsung yang ada dilapanga, lokasi enelitian dilakukan di Kecamatan Samatiga, Kabupaten Aceh Barat. Yang menjadi subjek dalam penelitian ini adalah petani dan pengusaha sawit di Samatiga, adapun yang menjadi polpulasinya adalah seluruh petani dan pengusaha dan diambil secara acak menggunakan metode sampling berjumlah 22 responden.

Model analisis data yang digunakan dalam penelitian ini yaitu dengan menggunakan analisis regresi linear berganda dengan persamaan sebesai berikut Persamaan faktor produksi

Model yang digunakan dalam penelitian ini bertitik tolak pada teori produksi. Bentuk umum fungsi produksi dapat ditulis sebagai berikut :

$$
Q=f(\mathrm{~K}, \mathrm{~L})
$$

Dimana : $Q=$ Output, $\mathrm{K}=$ modal, $\mathrm{L}=$ Luas Lahan

Kemudian model fungsi produksi pada persamaan (2.1) diatas dirubah dalam bentuk persamaan lagrangian untuk memperoleh fungsi permintaan tenaga kerja yaitu sebagai berikut :

$$
Q=f(K, L)
$$

Selanjutnya persamaan (2.2) diatas dirubah dalam bentuk regresi linier dengan menggunakan logaritma natural $(\mathrm{Ln})$ sehingga bentuk persamaannya menjadi sebagai berikut :

$$
\operatorname{Ln} \mathbf{L P}=\alpha+\beta_{1} \operatorname{LnK}+\beta_{2} \operatorname{LnL}
$$


Jurnal Bisnis dan Kajian Strategi Manajemen

Volume 2 Nomor 2, 2018

ISSN : 2614-2147

http://jurnal.utu.ac.id/jbkan

Persamaan diatas dapat ditulis dalam bentuk regresi linier sebagai berikut :

$$
\operatorname{Ln} \mathbf{L P}=\beta 0+\beta_{1} \operatorname{LnK}+\beta_{2} \operatorname{LnL}+\varepsilon
$$

Dimana :

$\mathrm{LP}=$ Jumlah produksi yang dihasilkan dengan satuannya adalah ton

$\mathrm{K}=$ jumlah jumlah modal yang digunakan dan satuan ukurannya dalam rupiah

$\mathrm{W}=$ Luas Lahan yang digunakan dengan satuanya adalah hektar

及o $=$ konstanta

$\beta=$ koefisien 


\section{HASIL DAN PEMBAHASAN}

\section{Karakteristik Petani Karet}

Karakteristik petani responden dalam penelitian digunakan untuk melihat gambaran atau keadaan dan ciri-ciri petani responden yang menjalankan usahatani karet di Kecamatan Samatiga Kabupaten Aceh Barat. Adapun karakteristik petani responden yang digunakan dalam penelitian ini meliputi umur, pendidikan, pengalaman, jumlah tanggungan dan luas lahan yang di usahakan petani.

Karakteristik ini memiliki keterkaitan erat dengan tingkat pendapatan yang diterima oleh petani dalam proses produksi, hal ini dikarenakan karakteristik mencerminkan kemampuan bekerja, produktivitas, pola pikir, perencanaan dan berbagai macam kemampuan lainnya dalam upaya meningkatkan pendapatan usahatani karet. Untuk melihat jelas bagaimana karakteristik petani responden dalam penelitian ini berikut diuraikan tentang karakteristik petani responden yang meliputi, umur petani, jenis kelamin, tingkat pendidikan, pengalaman berusahatani dan jumlah tangggungan petani.

\section{Umur Petani}

Umur petani merupakan salah saru faktor yang mempengaruhi tingkat kemampuan petani dalam mengelola usahataninya. Tenaga kerja produktif umumnya berada pada selang umur 24 hingga 61 tahun, sedangkan jika kurang atau lebih dari selang umur tersebut akan tergolong sebagai tenaga kerja kurang produktif tetapi masih termasuk dalam usia kerja. Karakteristik petani responden berdasarkan kelompok umur di Kecamatan Samatiga Kabupaten Aceh Barat dapat dilihat pada Tabel 4.1 berikut.

Tabel 4.1

Karakteristik Responden Petani Karet Menurut Kelompok Umur di Kecamatan Samatiga Kabupaten Aceh Barat

\begin{tabular}{|cccc|}
\hline No & Umur & Jumlah Reponden & $\begin{array}{c}\text { Persentase } \\
(\%)\end{array}$ \\
\hline 1 & $24-34$ & 4 & 18 \\
\hline 2 & $35-45$ & 4 & 18 \\
\hline 3 & $46-55$ & 7 & 32 \\
\hline 4 & $56-65$ & 7 & 32 \\
\hline & Total & 22 & 100 \\
\hline
\end{tabular}

Sumber: Data Primer 2017

Jika dilihat berdasarkan kelompok umur Tabel 4.1 menunjukkan bahwa umur paling banyak petani responden di Kecamatan Samatiga Kabupaten Aceh Barat berada pada kelompok umur 46-55 ddan 56-65 tahun tahun yaitu masing-masing 7 orang atau 32 persen dari jumlah petani, sedangkan yang paling sedikit terdapat pada kelompok umur 24-34 dan 35-45 tahun yaitu masing-masing 4 orang atau 18 persen dari jumlah petani dan rata-rata umur petani responden dalam penelitian ini 
yaitu 48 tahun. Kondisi tersebut menjelaskan bahwa sebagian besar petani responden dalam penelitian ini berada pada kelompok umur produktif. Dimana semakin produktif umur maka diharapkan dapat lebih baik dalam menjalankan usahataninya.

\section{Jenis Kelamin}

Karakteristik jenis kelamin digunakan untuk melihat jenis kelamin responden. Dimana biasanya jenis kelamin laki akan lebih produktif dibandingkan perempuan baik dari segi fisik maupun kemampuan berpikir dalam menjalankan usahataninya. Berikut disajikan karakteristik petani responden berdasarkan jenis kelamin.

Tabel 4.2

Karakteristik Responden Petani Karet Berdasarkan Jenis Kelamin di Kecamatan Samatiga Kabupaten Aceh Barat Tahun 2016

\begin{tabular}{|c|c|c|c|}
\hline \multirow{2}{*}{ No } & Jenis Kelamin & Jumlah Responden & Persentase \\
& & (Orang) & $(\%)$ \\
1 & Laki-laki & 19 & 86,36 \\
2 & Perempuan & 3 & 13,63 \\
Total & & 10 & 100 \\
\hline
\end{tabular}

Sumber : Data Primer, (Januari 2017)

Tabel 4.2 menunjukkan bahwa jenis kelamin responden dalam penelitian ini di dominasi oleh jenis kelamin laki-laki, dimana jenis kelamin laki-laki sebanyak 19 orang atau 86,36 persen dari jumlah petani, sedangkan jenis kelamin perempuan hanya 3 orang atau 13,63 persen dari jumlah petani. Hai ini menunjukkan bahwa petani responden dalam penelitian ini adalah petani produktif baik dari segi fisik maupun kemapuan berpikir.

\section{Tingkat Pendidikan}

Tingkat pendidikan akan berpengaruh terhadap tingkat adopsi teknologi dan inovasi yang sedang berkembang. Tingkat pendidikan merupakan faktor yang sangat penting yang menentukan tingkat kecakapan petani mengelola usaha taninya. Pada umumnya, semakin tinggi tingkat pendidikan seseorang, maka proses adopsi teknologi akan semakin cepat.

Adapun tujuan teknologi dan inovasi adalah untuk memperbaiki usaha tani baik dari segi produksi atau produktivitas. Untuk melihat gambaran jelas mengenai tingkat pendidikan petani reposden dalam penelitian ini di sajikan pada Tabel 4.3 berikut. 
Tabel 4.3

Karakteristik Responden Petani Karet Berdasarkan Tingkat Pendidikan di Kecamatan Samatiga Kabupaten Aceh Barat

\begin{tabular}{rccc}
\hline \multirow{2}{*}{ No } & Tingkat Pendidikan & $\begin{array}{c}\text { Jumlah } \\
\text { Responden }\end{array}$ & Persentase (\%) \\
\cline { 3 - 3 } & & (Orang) & \\
\hline 1 & Tidak Sekolah & 0 & 0 \\
2 & SD/Sederajat & 13 & 59,09 \\
3 & SMP/Sederajat & 3 & 13,64 \\
4 & SMA/Sederajat & 6 & 27,27 \\
5 & Universitas & 0 & 0 \\
\hline Jumlah & & 22 & 100 \\
\hline
\end{tabular}

Sumber : Data Primer, (Januari 2017)

Berdasarkan Tabel 4.3 menunjukkan bahwa tingkat pendidikan, petani responden dalam penelitian terkonsentrasi pada tingkat pendidikan SD sebanyak 13 orang atau sekitar 59,09 persen dari jumlah petani, dan tingkat pendidikan SMP berjumlah 3 orang serta yang berpendidikan SMA berjumlah 6 orang atau 27,27 persen dari jumlah petani.

\section{Pengalaman Berusahatani Karet}

Petani yang memiliki pengalaman berusahatani lebih lama akan lebih baik dan lebih matang dalam hal perencanaan usaha tani, karena lebih memahami berbagai aspek teknis dalam berusahatani. Demikian juga dengan berbagai masalah nonteknis yang biasanya dihadapi dalam berusahatani sehingga pada akhirnya produktivitas akan lebih tinggi. Karakteristik petani responden berdasarkan pengalaman dapat dilihat pada Tabel 4.4 berikut.

Tabel 4.4

Karakteristik Responden Petani Karet Berdasarkan Pengalaman di Kecamatan Samatiga Kabupaten Aceh Barat Tahun 2016

\begin{tabular}{cccc}
\hline \multirow{2}{*}{ No } & Pengalaman & Frekuensi & Persentase \\
\cline { 4 - 4 } & 1 & 13 & $(\%)$ \\
2 & $6-10$ & 6 & 59,09 \\
3 & $11-15$ & 2 & 27,27 \\
4 & $16-20$ & 1 & 9,09 \\
\hline & Jumlah & 22 & 4,55 \\
\hline
\end{tabular}

Sumber: Data Primer (2017)

Tabel 4.4 menunjukkan bahwa kelompok petani responden dengan jumlah yang paling banyak berdasarkan pengalaman usahatani adalah kelompok petani yang telah berusahatani karet 5-10 tahun yaitu sebanyak 4 orang atau 40 persen dari jumlah petani. Hanya 1 orang dari petani responden yang memiliki pengalaman berusahatani karet kurang dari 5 tahun serta 1 orang petani responden memiliki pengalaman lebih dari 20 tahun. 
Lebih lanjut berdasarkan data kuesioner sebagian petani responden menyatakan bahwa berusahatani karet merupakan usaha pokok untuk memenuhi kebutuhan beras sehingga rumah tangga petani tidak perlu membeli beras untuk pangan sehari-hari. Selain itu para petani juga berusahatani karet karena kondisi alam seperti ketersediaan air, kesuburan tanah, dan ketersediaan modal yang hanya sesuai dengan komoditas karet. Sedangkan petani yang memiliki usaha sampingan selain usahatani karet yaitu sebagai perangkat desa seperti Seketaris Desa (Sekdes), Usaha Kios dan ada juga yang bekerja kantoran serta berbagai macam usaha lainnya di luar usahatani karet, sesuai dengan keahlian dan permintaan tenaga kerja di daerah penelitian. Pekerjaan tersebut dilakukan petani untuk memperoleh sebagian modal guna di investasikan untuk membiayai sarana produksi usahataninya.

\section{Faktor-Faktor Produksi Karet}

\section{Luas Lahan}

Berdasarkan hasil penelitian maka diketahui luas lahan petani karet di Kecamatan Samatiga Kabupaten Aceh Barat pada tahun 2016 diuraikan pada Tabel 4.6 berikut.

Tabel 4.6

Luas Lahan Petani Karet di Kecamatan Samatiga Kabupaten Aceh Barat

\begin{tabular}{ccccr}
\hline \multirow{2}{*}{ No } & Luas Lahan & \multirow{2}{*}{ Frekuensi } & \multicolumn{2}{c}{ Persentase } \\
\cline { 2 - 2 } \cline { 5 - 5 }$(\%)$ \\
\hline 1 & $(\mathrm{Ha})$ & 12 & 54,55 \\
2 & 1 & 1 & 4,55 \\
3 & 1,2 & 2 & 9,09 \\
4 & 1,5 & 4 & 18,18 \\
5 & $1,6-2$ & 3 & 13,64 \\
\hline
\end{tabular}

Sumber : Data Primer, (Januari 2017)

Lahan merupakan faktor produksi yang sangat penting dalam usaha tani, tingginya luas lahan dapat mempengaruhi jumlah bibit yang ditaman, semakin besar luas lahan yang digarap petani maka semakin besar pula batang karet yang dapat ditanam.

\section{Modal}

Faktor produksi modal merupakan suatu unsur yang sangat penting dalam menjalankan usaha tani karet. Modal ini digunakan untuk melakukan perawatan kebun karet baik pembesihan kebun, pemupukan penyemprotan dan biaya operasional petani, sumua unsur tersebut dikatan sebagai modal berupa uang yang dikeluarkan untuk membiayai keperluan tersebut. Dari hasil penelitian jumlah modal yang dikeluarkan petani karet di Kecamatan Samatiga Kabupaten Aceh Barat berkisar antara Rp 300.000 Rp. 1.500 .000 per bulan, hal ini dapat dilihat pada Tabel 4.7 berikut. 
Tabel 4.7

Modal Petani Karet di Kecamatan Samatiga Kabupaten Aceh Barat

\begin{tabular}{cccc}
\hline \multirow{2}{*}{ No } & Modal (Ribu) & Jumlah Responden Orang) & \multicolumn{2}{c}{ Persentase } \\
\cline { 2 - 2 } \cline { 4 - 4 } & $(\mathrm{Rp})$ & 3 & $(\%)$ \\
\hline 1 & $300-400$ & 10 & 13,64 \\
2 & $500-550$ & 4 & 45,45 \\
3 & $551-650$ & 3 & 18,18 \\
4 & $651-700$ & 2 & 13,64 \\
5 & $701-1500$ & 22 & 9,09 \\
\hline
\end{tabular}

Sumber : Data Primer, (Januari 2017)

Tabel 4.7 menunjukkan bahwa modal yang di keluarkan petani karet di Kecamatan Samatiga Kabupaten Aceh Barat berkisar antara Rp 300.000 1.500 .000 per bulan, terdapat 2 orang petani yang mengeluarkan modal Rp. 300.000 per bulan, dan terdapat 10 orang petani dengan pengeluaran Rp 500.000 per bulan.

\section{Perkembangan Produksi Karet Responden di Kecamatan Samatiga Kabupaten Aceh Barat}

Produksi merupakan kunci dari usaha setiap pekerjaan yang dilakukan petani bertujuan untuk mencapai tingkat produksi yang tinggi. Berdasarkan hasil penelitian pekembangan produksi karet di Kecamatan Samatiga Kabupaten Aceh Barat dapat dilihat pada Tabel 4.8 berikut.

Tabel 4.8

Produksi Karet Responden di Kecamatan Samatiga Kabupaten Aceh Barat

\begin{tabular}{ccccr}
\hline \multirow{2}{*}{ No } & Produksi & \multirow{2}{*}{ Frekuensi } & \multicolumn{2}{c}{ Persentase } \\
\cline { 2 - 2 } \cline { 5 - 5 } & $(\mathrm{Kg})$ & & $(\%)$ & 13,64 \\
1 & $250-350$ & & 3 & 40,91 \\
2 & $351-550$ & & 9 & 22,73 \\
3 & $551-650$ & & 5 & 13,64 \\
4 & $651-750$ & & 3 & 9,09 \\
5 & $751-950$ & & 2 & 100,00 \\
\hline Jumlah & & 22 & \\
\hline
\end{tabular}

Tabel 4.8 menunjukkan bahwa tingkat produksi karet di Kecamatan Samatiga Kabupaten Aceh Barat berkisar antara 250-920 kg per bulan. Produksi terendah yaitu $250 \mathrm{~kg}$, dan produksi tertinggi yaitu sebesar $920 \mathrm{Kg}$. Terdapat 9 orang responden dengan tingkat produksi $450 \mathrm{Kg}$ atau 40,91 persen dari jumlah petani dan 4 orang responden dengan tingkat produksi $580 \mathrm{Kg}$ atau 18,18 persen dari jumlah petani.

\section{Analisis Regresi Linear Berganda}

Hasil perhitungan analisis regresi linear berganda dalam penelitian ini dapat dilihat pada Tabel 4.9 dibawah ini. 
Tabel 4.9

Coefficients

\begin{tabular}{|c|c|c|c|c|c|}
\hline \multirow[t]{2}{*}{ Model } & \multicolumn{2}{|c|}{$\begin{array}{l}\text { Unstandardized } \\
\text { Coefficients }\end{array}$} & \multirow{2}{*}{$\begin{array}{l}\text { Standardized } \\
\text { Coefficients } \\
\text { Beta }\end{array}$} & \multirow[t]{2}{*}{$\mathrm{t}$} & \multirow[t]{2}{*}{ Sig. } \\
\hline & B & Std. Error & & & \\
\hline (Constant) & 59,751 & 51,221 & & , 199 &, 147 \\
\hline LnK & 2,783 & 78,348 &, 005 & 0,34 & 0,0974 \\
\hline $\mathrm{LnL}$ & 0,017 &, 000 &, 252 & 2,015 & 0,0 \\
\hline
\end{tabular}

Berdasarkan Tabel 4.9 maka diperoleh persamaan regresinya sebagai berikut:

$\mathbf{L n} \mathbf{L P}=\boldsymbol{\beta}_{0}+\boldsymbol{\beta}_{1} \mathbf{L n K}+\boldsymbol{\beta}_{2} \mathbf{L n L}+\varepsilon$

$Y=59,751+2873 \mathrm{LnK}+0,017 \mathrm{LnL}$

Persamaan tersebut dapat dijelaskan sebagai berikut:

1. Konstanta

Dari persamaan tersebut dapat dilihat bahwa nilai konstanta sebesar 59,751.

Nilai konstanta ini menyatakan bahwa apabila variabel luas lahan jumlah pohon karet dan modal petani tidak mengalami perubahan atau tetap maka produksi karet di Kecamatan Samatiga Kabupaten Aceh Barat sebesar 59,751 Kg.

2. Koefisien Regresi LnK ( luas lahan)

Koefisien regresi luas lahan sebesar 2,783 yang berarti bahwa setiap penambahan luas lahan 1 hektar meningkatkan produksi karet di Kecamatan Samatiga Kabupaten Aceh Barat sebesar 2,783 Kg.

3. Koefisien Regresi Modal (LnL)

Dari persamaan tersebut dapat dilihat bahwa nilai koefisien regresi modal $(\mathrm{LnL})$ sebesar 0,01. Hal ini menyatakan bahwa apabila terjadi penambahan modal seratus ribu rupiah maka akan meningkatkan produksi karet di Kecamatan Samatiga Kabupaten Aceh Barat sebesar 0,017 Kg.

\section{Pengujian Hipotesis}

\section{Uji t}

Pengujian hipotesis secara parsial dengan menggunakan "uji t" pada tingkat kepercayaan 95 persen $(\alpha=0,05)$ diperoleh hasil sebagai berikut :

a. Variabel luas lahan diperoleh nilai $t_{\text {hitung }}$ sebesar $0,034<t_{\text {tabel }} 1,72$. Artinya bahwa secara parsial variabel luas lahan $\left(\mathrm{X}_{1}\right)$ tidak berpengaruh nyata terhadap produksi karet di Kecamatan Samatiga Kabupaten Kabupaten Aceh Barat.

b. Variabel modal diperoleh $t_{\text {hitung }}$ sebesar 2,015 $>t_{\text {tabel }}$ sebesar 1,72. Artinya bahwa secara parsial variabel modal (X3) berpengaruh nyata terhadap produksi karet di Kecamatan Samatiga Kabupaten Aceh Barat. 


\section{Uji F}

Uji $\mathrm{F}$ ini digunakan untuk melihat ada tidaknya pengaruh antara variabel luas lahan, jumlah pohon karet dan modal secara bersama-sama terhadap produksi karet di Kecamatan Samatiga Kabupaten Aceh Barat, hasilnya dapat dilihat pada Tabel 4.10.

\begin{tabular}{|l|l|r|r|r|r|r|}
\hline \multicolumn{2}{|l|}{ Model } & $\begin{array}{c}\text { Sum of } \\
\text { Squares }\end{array}$ & df & Mean Square & F & Sig. \\
\hline \multirow{4}{*}{1} & Regression & 592244,160 & 2 & 296122,080 & 114,298 &, $000^{\mathrm{b}}$ \\
\cline { 2 - 8 } & Residual & 49225,158 & 19 & 2590,798 & & \\
\cline { 2 - 8 } & Total & 641469,318 & 21 & & & \\
\hline
\end{tabular}

Sumber : Hasil Regresi SPSS ( Februari 2017)

Tabel 4.10 di atas diperoleh $F_{\text {hitung }}$ sebesar 114,298 $>F_{\text {tabel }}$ yakni 3,07. Artinya bahwa variabel luas lahan $\left(\mathrm{X}_{1}\right)$ dan modal $\left(\mathrm{X}_{2}\right)$ secara bersama-sama (serempak) berpengaruh nyata terhadap produksi karet di Kecamatan Samatiga Kabupaten Aceh Barat.

\section{Pembahasan Hasil}

\section{Hubungan Modal Terhadap Produksi}

Dari hasil penelitian diatas menunjukkan bahwa hubungan modal terhadap produksi karet di kecamatan adalah positif dan signifikan, dengan nilai signifikasinya sebesar 0,097 atau lebih kecil dari batas toleran yang ditentukan yaitu $<0,10$. Memiliki nilai koefisien regresi sebesar 2,783 yang memiliki makna bahwa setiap kenaikan modal sebesar 1 persen maka akan berpengaruh terhadap peningkatan jumlah produksi sebesar 2,7 ton. Penelitian ini mendukung penyataan Pindyck \& Rubinfeld (2009, h. 211) yang menerangkan bahwa modal berpengaruh secara positif dan siginifikan terhadap produksi karet.

\section{Hubungan Luas Lahan Terhadap Produksi}

Luas lahan merupakan faktor yang sangat penting dalam produksi karet, hubungan luas lahan terhadap produksi karet memiliki pengaruh fositif dan signifikan dengan nilai signifikasinya sebesar 0,00 . Nilai koefisien regresi sebesar 0,017 memiliki makna bahwa setiap kenaikan luas lahan sebesar 1 persen akan mempengaruhi produksi sebesar 0,017 ton. Penelitian ini Setiadi (2012) dan Syahbidan (2014) yang menyatakan bahwa luas lahan berepngaruh fositif dan signifikan terhadap produksi

\section{KESIMPULAN}

1. Faktor produksi yang paling besar pengaruhnya terhadap produksi karet adalah jumlah penggunaan modal yaitu sebesar 2,783 dibandingkan luas lahan sebesar 0,017. Hubungan kedua variabel tersebut terhadap produksi karet adalah fositif dan signifikan. 
Jurnal Bisnis dan Kajian Strategi Manajemen

Volume 2 Nomor 2, 2018

ISSN : 2614-2147

http://jurnal.utu.ac.id/jbkan

2. Untuk meningkatkan produksi karet maka manajemen produksi yang harus diterapkan adalah dengan menambah jumlah modal, seperti, penggunaan pupuk, penggunaan bibit unggul dan penggunaan modal. 
Daftar Pustaka

Badan Pusat Statistik (BPS) Provinsi Aceh 2017

Badan Pusat Statistik (BPS) Aceh Barat 2017

Mulyadi S. 2003. Ekonomi Sumber Daya manusia dalam Perspektif Pembangunan. PT. Raja Grafindo Persada: Jakarta.

Nababan, PWJ. 1984. Sosiolinguistik suatu Pengantar. Jakarta : PT Gramedia Pustaka Utama

Partomo TS, Soejoedono AR. 2004. Ekonomi Skala Kecil/Menengah dan Koperasi. Ghalia Indonesia: Jakarta.

Robert Pindyck \& Daniel L. Rubinfeld. 2007. Mikroekonomi edisi keenam. Indeks: Jakarta

Sukirno, Sadono. 2009. Mikro Ekonomi Teori Pengantar Edisi ketiga. PT. RajaGrafindo Persada: Jakarta

Sadono Sukirno. 2006. Mikro Ekonomi Teori Pengantar. Edisi Ketiga. Jakarta: Rajagrafindo Persada.

Sudarman, A., 2004. Teori Ekonomi MikroI. BFE Yogyakarta.Yogyakarta

Sukirno S. 2005. Mikro Ekonomi Manajemen SDM, Ketenagakerjaan. Graha Ilmu: Yogyakarta. 